DOI: 10.36340/2071-6818-2021-17-1-10-28

The journal traditionally opens with an academic interview. In this issue, we present the director of the Tretyakov Gallery Zelfira Tregulova, who kindly agreed to answer questions from Maria Burganova, the Editor in chief of The Burganov House. The Space of Culture journal. 


\section{INTERVIEW WITH THE DIRECTOR OF THE TRETYAKOV GALLERY ZELFIRA TREGULOVA}

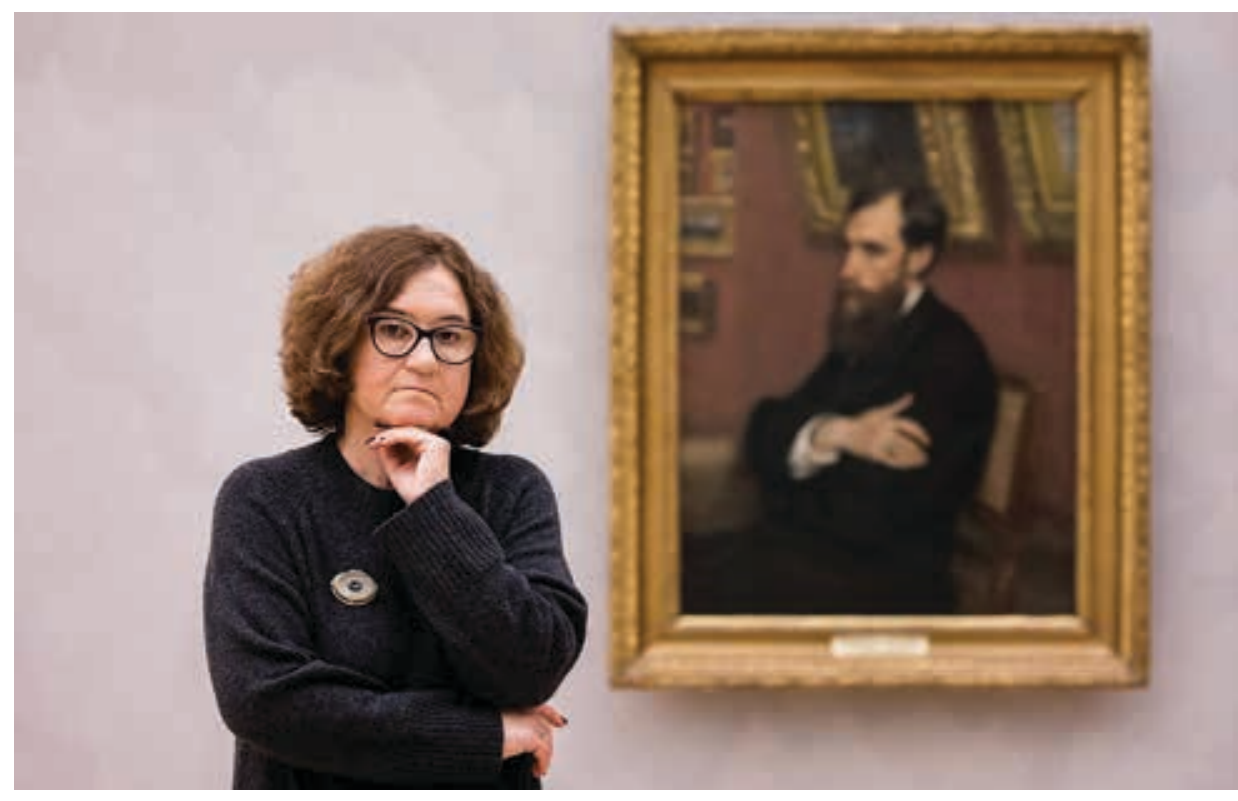

Ill. 1. Zelfira Tregulova Photo (C) Evgeny Alekseev, Tretyakov Gallery

Maria Burganova: The Tretyakov Gallery is a treasury of Russian art, a symbol of Russian culture. For some people, it is a place of pilgrimage; for others, it is part of their biography. In this regard, it is easier to choose conservatism as a strategy of existence. The accumulated masterpieces are already a guarantee of stability, which is so needed in the modern world. However, today, the Museum, having chosen a rapid pace in the art world, is increasingly associated with the avant-garde in culture and topical processes in art.

Do new development strategies overshadow the recognizable and beloved image of the traditional Moscow museum?

Zelfira Tregulova: It is clear that for a considerable number of people, the Tretyakov Gallery is associated with the building in Lavrushinsky Lane, with the classical exposition of Russian art, starting chronologically from the Old Russian art, and then, from the $18^{\text {th }}$ century to Symbolism and the Blue Rose. The collection of old Russian icons in the Tretyakov Gallery is stunning and magnificent. It is challenging to compare it with anything.

However, let us consider the following. Pavel Tretyakov, a man, who at the age of 26 began collect- ing works of art, bought, for example, a painting A Clash with Finnish Smugglers by artist V. Khudyakov or a painting Temptation by N. Schilder depicting a procuress who comes to a low-income family's house where there are a sick mother and a beautiful young girl... These are paintings in which the plot and edification prevail. At the age of 26 , before going abroad for the first time, Tretyakov wrote a testament in which he formulated his credo - creating a museum representing the national school, a museum which "will be useful for many and bring pleasure for everyone". And what does this man, who visited 253 European cities in his life, begin to do? If you add up the trips of all of us, a few people put together, who have been very active over the past thirty years, there will not be 253 European cities. Anywhere Tretyakov went, he got acquainted with the latest technologies of textile production, simultaneously visiting museums. So what did he start to collect? He began to collect contemporary art, to acquire works of the young Itinerants, who were not even thirty, the artworks of young Repin. In the end, in later years, if you remember, Tretyakov bought Sunlit Girl by V. Serov. This is 1888. A year earlier, he tried to acquire Girl with Peaches. So, as soon 


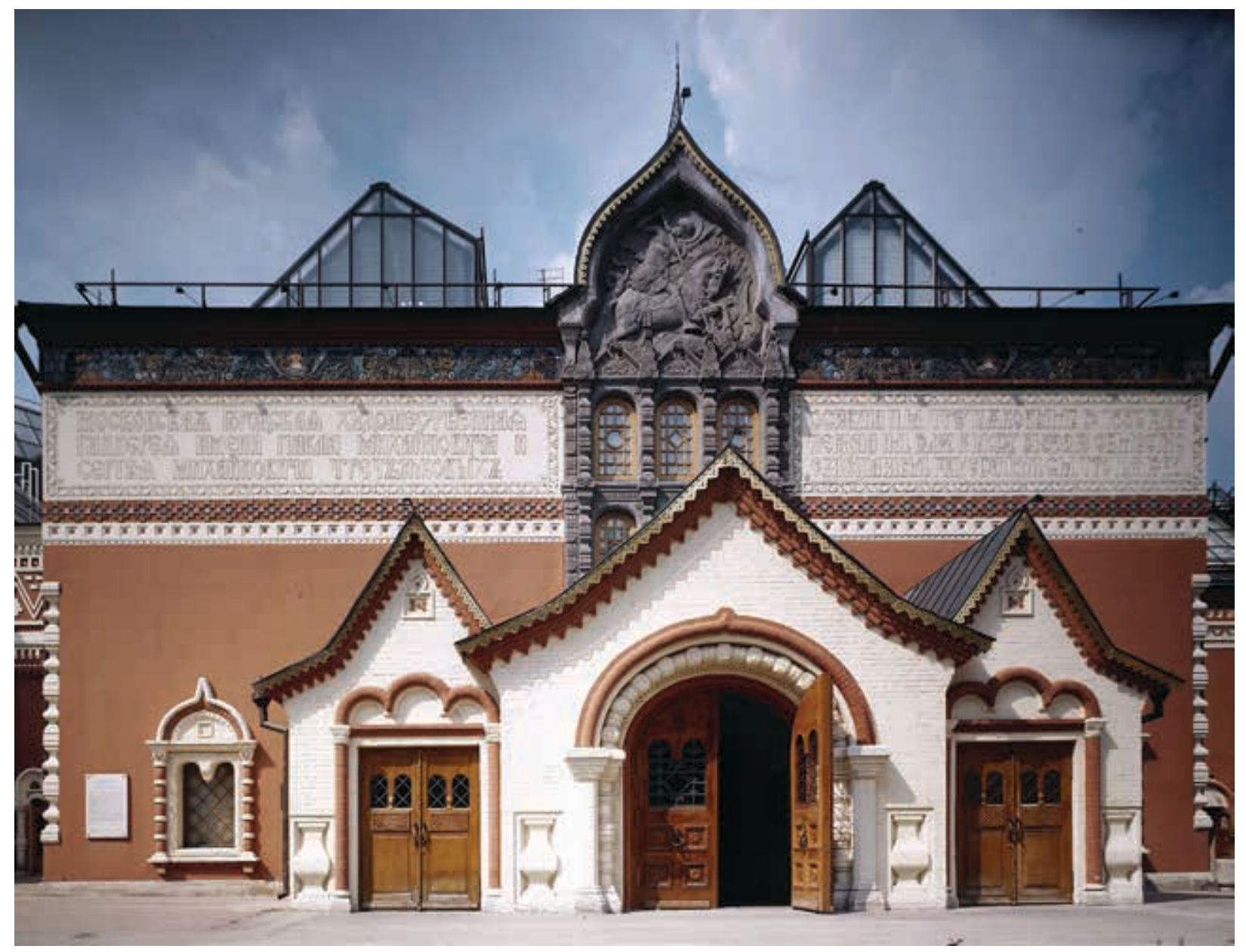

Ill. 2. The Tretyakov Gallery

as he purchased Sunlit Girl, he immediately faced evil and sometimes vulgar criticism. Just like Renoir for his stunning Nude with blue shadows, the one that is now in the Pushkin Museum. Very similar...

He bought artworks of Vereshchagin, whose paintings drew severe criticism for the lack of patriotism. The persecution developed to such an extent that, as is known, Vereshchagin burned three or four works that drew the fiercest criticism. Tretyakov bought his entire Turkestan Series with such ambiguous, even for today's perception, works such as The Apotheosis of War. The same can be said about the purchase of Ivan the Terrible and His Son Ivan, which was attacked for the first time in 1913.

If you walk through the halls of the Tretyakov Gallery, it is clear that, indeed, Tretyakov collected contemporary art, sensing the most important artists - his intuition was amazing. He ordered artworks, buying the best works in the studio; sometimes, the paints had not yet dried on some of them.

Today, in the minds of many, the image of Pavel Tretyakov has been formed as a stern man in a buttoned-up frock coat. In fact, he was a man of incredible courage, who, being a very successful businessperson spent his entire life creating a museum of the Russian national school. A museum that neither the state nor the Sovereign Emperor thought about at that time.

Therefore, collecting contemporary art and demonstrating it is the historically established role of the Tretyakov Gallery. Moreover, this is objectively so. It must be remembered that the artists of the artworks, which Tretyakov bought, were very young people. Yes, it is true, at that time, they grew up early and acquired maturity earlier. Let us remember Barge Haulers on the Volga. Repin, when he began to work on this painting, was 26 years old.

Tretyakov also bought works by Nikolai Ge, which were not shown during his lifetime since they were prohibited by censorship. They were hung behind black curtains. Moreover, Tretyakov did not live to see the moment when the ban on censorship of Ge's paintings was lifted.

Later, the collection of Mikhail Morozov, who died in 1903, was added to the Tretyakov Gallery collection. The collection included the brilliant Jeanne Sa- 
mary by Renoir, Girls on the Bridge by Edvard Munch. Subsequently, the works, which after 1917 were separated from Russian artists' works, were distributed between the Pushkin Museum of Fine Arts and the Hermitage.

To my mind, not a single museum that collects works of an incredible large chronological segment, a museum of national art, can put an end to it at some point and stop buying what is contemporary and relevant, not in the sense of defining the meaning of relevant art but the art that is born today. Yes, the question is raised: how can one know that this artist will be great? Well, Pavel Tretyakov also collected works that, today, do not seem to be the works of great artists; however, they are interesting in any case. Nowadays, we are trying to present the same Itinerants with famous artworks and show what is usually found in the funds. This creates a fascinating context for these principal masterpieces. There are many discoveries there, and in fact, we were too conservative in our understanding of what Russian art is for a very long time. Soviet art history contributed significantly to this.

In addition, today, we not only show contemporary art and accept it as a gift, since the opportunities to buy are extremely limited, but we also create very modern exhibitions of classical Russian art. Each of these exhibitions has some kind of contemporary lens, some sort of modern focus. Exhibitions that try to discard preconceived opinions, clichés strive to analyze the artistic phenomenon as objectively as possible, return the meanings that were present at its birth, to this art. The meanings that were noticed by the criticism of that time but which were forgotten entirely during the years of Soviet power, which were not paid attention to and were erased from consciousness. There are many examples of misinterpretation by Soviet art history. For example, The Unknown Woman by Kramskoy... You probably remember well the time when it was said that it was Anna Karenina. Afterwards, I experienced a real shock when Mikhail Allenov, our university teacher and my teacher, explained that this was a lady of the half-light on the Anichkov Bridge, that we had lost the social code; a woman of high social status could not be in an open carriage without an attendant, without a veil during the day. Or They Didn't Expect Him - a work on a modern plot, in which only topicality was seen in the Soviet years. In fact, Repin's contemporaries understood perfectly well that this was a paraphrase of both The Appearance of Christ to the People and The Parable of the Prodigal Son. This Christian iconography and attempts to address eternal themes, for example, by Repin, were suppressed for a considerable number of decades. Today, we return these meanings again. And it becomes fascinating and relevant. With these exhibitions, in fact, we are writing a new history of Russian art.

In the building of the Tretyakov Gallery on Krymsky Val, for many years, when I had not yet worked in the gallery, each visit to this building aroused a painful question because only around 20 coats could be seen in the big wardrobe unless there was an exhibition of Levitan or Nesterov. You remember very well the empty halls at the avant-garde exhibitions. It might be possible the visitors were at the first two or three exhibitions - of Malevich, Filonov, Popova in the 1990s... It was as if a curse hung over this building, this space. Therefore, in recent years, we have made a tremendous amount of effort to make people proud of the Russian avant-garde, to make people understand that the highest achievements mark Russian art of the $20^{\text {th }}$ century; moreover, achievements of a world scale, no less, and sometimes even more than the classical Russian art.

Nowadays, this imbalance is leveled out a little since the $20^{\text {th }}$ century's Russian art arouses greater interest as time goes on. At the same time, a very modern approach to displaying Russian art is being formed - the approach which has provided us with these gigantic queues. The queue for Serov was almost 500 thousand people. 600 thousand for Aivazovsky. When we started working on this exhibition, I thought: how will we show Aivazovsky today? And you just had to discard snobbery, look closer. It is no coincidence that he was called Russian Turner. This confrontation of the universal elements became the essential theme of the creativity of both. And in fact, Aivazovsky's best paintings are about the omnipotence of the elements and the insignificance of a human compared to the universe's scale. We began this exhibition with the Blue Soup group's video art - the endlessly moving sea that never parts before you. A completely hypnotizing sight, you know. And immediately, on entering the exhibition, the optics tuned in not to the beautiful lunar and sunset seascapes, which are in such demand on the art market; the viewer began to look for something else in this artist. Deeper meanings. And he was a person familiar with the most profound philosophical and religious teachings. His brother Gabriel lived for many years in the monastery of St. Lazarus in Venice. 




Ill. 3. New Tretyakov Gallery

It is my deepest conviction that today, a museum cannot be conservative. Nowadays, the role of the museum is incredibly active. And the museum can do a lot nowadays. It is not fashion, as many say. However, what is wrong with the fact that it is fashionable to go to museums? Before the pandemic onset, Krymsky Val was a vibrant, active, seething place where many things happened at once. There were concerts, philosophical discussions, lectures, film screenings, exhibitions, and many kinds of things. We restored the courtyard, created a cafe where people met; thus, we made it an essential public space. Today, people who are more and more isolated from each other and their loved ones feel a particular need to socialize. And so, among other things, the museum becomes a place of socialization. These are incredible emotions; this is a counterbalance, counteraction to fakes because art always speaks the truth, its truth, it does not lie. Well, if it is the real art. A priori, what we show is the real art. These are incredible emotions that we lack in everyday life, which is incredibly hectic, primarily focused on work. A museum is a place where you can come with your family. Well, and do a lot of things more. It is wrong not to understand this change, this social role of the museum.

M. B.: Recently, the Tretyakov Gallery has carried out several projects representing the dialogue of cultures. For example, you collaborated with the Pompidou Center, the Ludwig Museum, and the Tate Gallery in order to present the work of M. Larionov. In 2019, an exposition of Norwegian painter E. Munch was launched at your museum; in 2020 - a large-scale project The Piscator's Bible - a Handbook of Russian Icon Painters. There are many examples.

How is our national museum perceived in the international art space?

Z. T.: It is also a good question that no one has asked before. We have recently completed several very important, top-class - I can safely say this - international projects. First, I would like to highlight three great alliances with the most serious European museums; soon, there will be a fourth. The first project is a project with the National Portrait Gallery in London. We made an exchange with them: an exhibition of 49 portraits from the permanent exhibition of the National Portrait Gallery were brought. In response, they sent 26 of the best portraits by Russian artists. Our exhibition aroused great interest. London colleagues allocated two relatively small exhibition rooms for it. Afterwards, they regretted it since people crowded like herrings in a barrel there. We gave the best works, and they gave their best works.

The second exchange was with the Vatican Museums. And at the same time, we followed the principle of parity. Each time we gave the Western curators, who formed an exhibition from the Tretyakov Gallery's collection, carte blanche; however, in response, we also asked for carte blanche to form an exhibition from their collection. It worked incredibly well. I invited Arkady Ippolitov to be the curator of the Vatican project. We coincided with the selection of the main works for the exhibition, including Caravaggio's Entombment of Christ. These were 42 paintings from the walls of the Vatican Pinakothek. Not 
a single artwork came from the art depository. The Entombment of Christ by Caravaggio; The Martyrdom of Saint Erasmus by Poussin, painted for the Cathedral of Saint Peter, 3 meters $20 \mathrm{~cm}$ high; the stunning, phenomenal Lamentation over the Dead Christ by Giovanni Bellini; three of the five Angels of Melozzo da Forli, which are the symbol-sign of the Vatican Pinakothek; Raphael...; Veronese...; the world's first depiction of Francis of Assisi from the early $13^{\text {th }}$ century; the $11^{\text {th }}$-century icon, created before the schism, depicting the Savior; the phenomenal Lamentation over the Dead Christ by Crivelli. I am saying this, and it gives me goosebumps.

The artworks we had sent to the Vatican Museums were presented in the Charlemagne wing of St. Peter's Basilica. Sergei Tchoban made a stunning exposition built into Bernini's architecture. Space rose, and the passage through the exhibition was like a kind of ascent. The exhibition's curators, Arkady Ippolitov and Tatiana Yudenkova, proposed an interesting move - the exhibition was called The Russian Way: From Dionysius to Malevich. For the first time in history, ancient Russian icon painting was shown together with a secular painting of the second half of the $19^{\text {th }}$ - early $20^{\text {th }}$ centuries, demonstrating that Russian art is a single whole. When Malevich's Black Square hung next to the huge Novgorod icon of the $16^{\text {th }}$ century, The Last Judgment, everything was clear. When Christ in the Desert by Ivan Kramskoy was very close to the portrait of Dostoevsky by Vasily Perov, and there was a Permian wooden sculpture in the center of the hall in front of them, it became clear that both Christ from Perm and Kramskoy's Christ and Dostoevsky had this same concentrated expression on their faces, the same painfully clenched hands and the same painful questions arose before the inner gaze.

I had the phenomenal privilege of showing this exhibition to Pope Francis for 40 minutes. And to be honest, I was nervous because his English is not very good and my Italian is frankly bad. However, when he stopped at these three works, he looked around and said: "Look, this is the same image," that is, he saw Kramskoy's Christ in Dostoevsky. And I must add that Perov's portrait of Dostoevsky and Christ in the Desert by Kramskoy were created in the same year, in 1872 .

The third exchange was our exhibition at the Munch Museum in Oslo, representing the art of the turn of the $20^{\text {th }}$ century. It became the most visited exhibition in the history of the Munch Museum. And the phenomenal Munch exhibition from the Munch Museum collection, which was closed at that time, here. The Norwegian museum director said it was the best exhibition of Munch in their museum's collection in decades.

And now we have an exchange with Helsinki. Together with the Russian Museum, we are sending Repin's artworks to the Athenaeum Museum, and in 2022, we are accepting an exhibition of the prominent Finnish artist, Akseli Gallen-Kallela. Again, the museum in Helsinki will be closed for reconstruction, and we will bring all the most unique art pieces.

Answering the question, if we had not raised the degree of our reputation in the world now, we probably would not have received all these phenomenal masterpieces under our roof, including the earliest version of The Scream by E. Munch. Not to mention Entombment by Caravaggio. Honestly, until the exhibition was taken back to Rome and unpacked, I went to bed every night with the thought, "Oh God! Please, let everything, everything, be good". Never before were there such artworks of global status, except for the avant-garde, under the Tretyakov Gallery's roof. But still, when we talk about Caravaggio's Entombment of Christ, it is necessary to realize that this is one of the main masterpieces of world painting. In addition, we were entrusted with it. There have never been any financial conditions to pay for the provision of works with any of these museums. Of course not. Moreover, this is cooperation, parity. It may be, so to say, off records, but only four years ago, the Tretyakov Gallery became a member of the Bizo group - a community of directors of the world's largest museums, participants in the international exhibition process. And I became the first director of the Museum of National Russian Art, which was included in this group. Of course, the situation has changed in recent years. It is clear that we are a top-rated museum when it comes to the collection of the Russian avant-garde. The number of requests for this part of the collection is enormous compared to our other collections. And whenever we are offered to participate in some serious, important project, we try to participate in it both with the avant-garde and the art of the $19^{\text {th }}$ century.

For example, in Petit Palais in Paris a few years ago, there was an exhibition L'art de la Paix (The Art of Peace), dedicated to the theme of peace. It began with a treaty signed by Charlemagne from the National Library in Paris and ended with The 


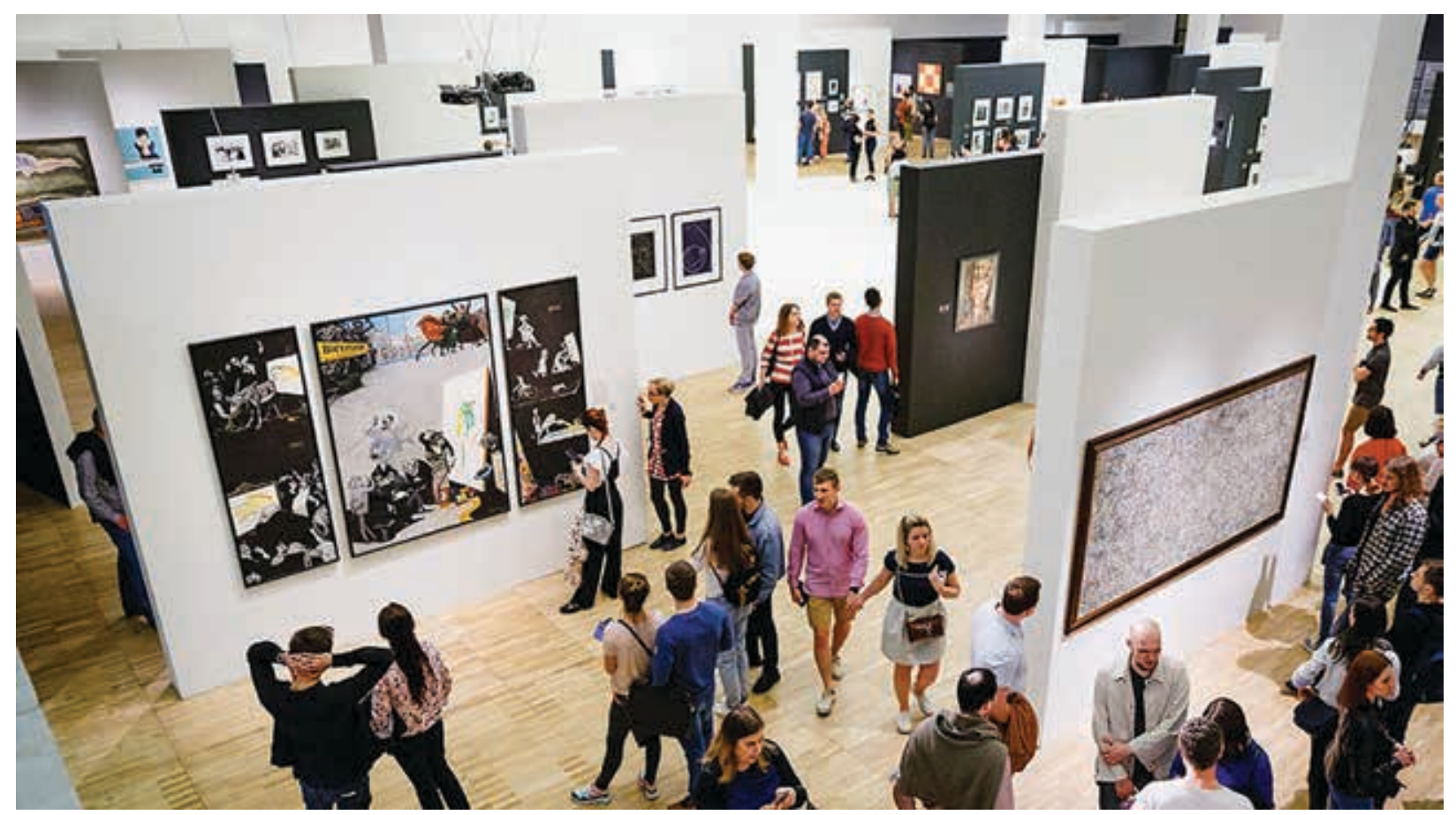

Ill. 4. The Tretyakov Gallery

Apotheosis of War by Vereshchagin. And this painting symbolized an incredible call to everyone: not to wage war.

Exhibitions from our collections can be regularly seen abroad, in particular in China. Several years ago, our exhibition of the Itinerants was recognized as the best exhibition of $19^{\text {th }}$-century art in the world that year. And this is understandable - Evening Bell, The Unknown Woman by Kramskoy - the Chinese just cried at the opening. It is not an exaggeration. Ten professors from the local Academy of Arts, who had once studied in Russia or with Russian teachers, were invited to the opening day. In addition, these people touched the frame of The Unknown Wom$a n$ as if it was an icon.

M. B.: In the program of exhibition projects of the Tretyakov Gallery, 2021 has been marked by the remarkable project "Laboratory of the Future. Kinetic Art in Russia", which is dedicated to one of the most interesting areas of contemporary art - kinetic art. Naum Gabo, Vyacheslav Koleichuk, El Lissitzky, Natan Pevzner, Alexander Rodchenko, Vladimir Tatlin, and many others are among the artists. It is a largescale project that brings together hundreds of masterpieces. How did the realization of its necessity come? It is known that at present, it is planned to recreate and install a 13-meter light and dynamic composition Atom by V. Koleichuk in Moscow.

Does this indicate new trends in the cultural space of the city?
Z. T.: About kineticism. When you enter the exhibition, you get goosebumps. It is great. Moreover, this is a very subtle and clever story. It is an incredible exposition, as if telling about our birthright, I mean constructivism. In fact, this is the rare case when Vyacheslav Koleichuk's reconstructions of works by Constructivists do not look like a remake. It is the same concept reborn over many decades. The exhibition vividly tells how constructivism's ideas are intertwined with the works of the late $50 \mathrm{~s}-$ early 60 s of the Thaw artists. You understand their connection with constructivism, and you understand that this is an entirely different - another stage. These works from 1959-1962 are incredible in their originality and boldness. Stalin died in 1953; there was an iron curtain. What we see in the works of young Francisco Infante, Lev Nusberg, Igor Zlotnikov is not only interest in contemporary art of the West, information obtained indirectly through Polish art magazines. It is the birth of similar ideas in the minds of young Soviet artists; ideas that were relevant for the late 1950s - early 1960s, ideas that Soviet artists sometimes had a year and a half earlier than their Western European colleagues. Peter Weibel, Director of the ZKM in Karlsruhe, spoke about this when we worked on the exhibition Europe Facing the Future, which took place in the Pushkin Museum. I was connected with this project when I was still the Director of ROSIZO. Indeed, comparing the dates, he said that the Soviet Union and Zagreb were the first 
points where the kinetics and geometric abstraction of this period had been born. Well, we are not taking into account monumental geometric abstraction and American abstract expressionism. We are talking about Europe. It is then exciting to see how constructivism's best ideas, the Thaw artists' ideas become relevant again in contemporary artists' works. This process is fascinating to follow. The exposition is structured in such a way that any passage through this exhibition is an incredible journey with an ever-changing point of view. Indeed, I did not think it would be so delightful. I am happy that there are many works by Vyacheslav Koleichuk at this exhibition as I feel guilty that we could not organize his exhibition during his lifetime. Now we will do it.

This kinship of kinetic art with the Russian avantgarde is the essence of any emergence of similar ideas on the artistic process's surface. It is a feature of Russian art of the $20^{\text {th }}$ century. In addition, we want to show this. We have the most considerable collection of the Russian avant-garde, and somewhere at the genetic level, at the level of the concept of artistic identity in an effort to always reach the absolute, to achieve the final expression of ideas, we understand that it is essential to communicate this heritage.

When in 2011, after the Picasso exhibition in Moscow, I came to the Picasso Museum in Paris, which was opened after reconstruction, I began to ask myself questions. I saw Picasso's graphic sheets with protosuprimatic elements from 1913-1914, as well as paper and cardboard-like counter-reliefs of the same period. Moreover, immediately, a comparison with Russian art appeared - with the works of Malevich and Tatlin. They are opposite artists; however, at that moment, they both were going through a period of most profound admiration for Picasso. Picasso was the first who approached these two ideas of protosuprematism and protoconstructivism; and, probably, afterwards, his passion for painting and temperament, in general, turned his work in a different direction. And the Russians, Malevich and Tatlin, developed it to the absolute. Malevich's Black Square, Tatlin's Counter-relief, Rodchenko's Three Colors. Yellow. Red. Blue and Rozanova's Green Stripe were the most radical works of art of the 1910s. In addition, look what was left to do for the postwar American geometric abstraction? Nothing. Everything was said.

M. B.: Due to Covid-2019, the cultural space has become virtual. There are advantages here - you can visit museums in Moscow and Paris in one day. However, there are also drawbacks. The impossibility of seeing the original and the impossibility of being in museum halls are among them.

Is it worth regretting the onset of a new virtual era in culture? Is it possible to preserve the museum's uniqueness in this context since media tools are universal and impersonal?

Z. T.: I have already said, and I am deeply convinced that one does not interfere with the other. You and I regularly went to museums. We frequently came into contact with works of art, often went to theaters and concerts. Then, in the spring, at the beginning of summer 2020, there were three and a half months of absolute quarantine. A period when there was no alternative, when we worked in Zoom from ten to seven, feeling as if a roller had passed over you at the end of the day because, in order to convey the energy necessary for proper communication through this neutral virtual space, you spend much more of it than when you communicate live.

So, we all passed the same evenings in the online art space these three and a half months. In addition, it saved us. However, at the same time, everyone perfectly understood that they wanted to be back in a real museum space in front of actual works. In early spring 2020, we knew perfectly well that our museum would be closed. Thus, we rushed to create online content, including films like The Tretyakov Gallery with Sergei Shnurov. Moreover, I think we have made a new format for an online conversation about art in a museum. It was not a prepared text; it was not rehearsed; it was a real improvisation. A sense of spontaneity was created. A feeling that you are standing behind the backs of these two people, so different, talking about this or that painting. And with Shnurov, I must say, it was very interesting.

How much I wished to return to the museum then, to return to the concert hall. When I heard about Matsuev's concert in the Tchaikovsky Concert Hall, the first after the quarantine, I immediately ran to listen and realized that even though during the quarantine, I had been living in portable headphones, endlessly listening to classical music as I had to fill this vacuum with something that would keep you afloat, it was necessary to return to a real concert hall or the space of a museum. When you listen to live music, you understand that you are ready to go to these concerts, to real museums endlessly. 
Yes, of course, thanks to the situation with online activities, we could make a giant breakthrough. During this time, the audience has increased significantly. We had 10 million views of our online content over the past year. On YouTube, we are the first in the world in terms of the number of subscribers. In addition, the program Tretyakov Gallery with Shnurov was watched by one million one hundred thousand people on YouTube. And these one million one hundred thousand people realized that the museum is not a boring place to where an "obligatory teacher" takes you, to where you will never return and certainly will not bring your children. At the same time, in no way did we try to work in such a way that it would be pure populism. Many told me that they waited until the end when finally Shnurov would start using profanity. However, it did not happen and could not happen - he is a knowledgeable and educated person.

That is why these are complementary realities for me. When the doors of museums, concert halls, theaters close in times of coronavirus, online is the only alternative. You tune in to the energy of recordings, videos, audios. However, when you later can return to the original, you subconsciously compare and understand the considerable difference between the real and the virtual. Therefore, I am absolutely not afraid that virtual reality will supplant a real museum in this case. On the contrary, it will prepare the audience, intrigue them. Though, very modern content is needed for this. Modern, not in the sense of technology. For example, we shot a film about the Tretyakov Gallery with Shnurov, then about the Tretyakov Gallery with Khabensky, using three or four cameras. No composite footage, no virtual reality. It was a live, real shoot. And it was not boring. It was alive; you could see emotions on the faces of the speakers. You absorbed their energy. Through you, this divine meaning, contained in every piece of art, was transmitted to those people who were sitting in front of the screens of TVs, computers, iPads, iPhones - whatever.

M. B.: Society creates a museum; a museum creates a society. What is the responsibility of the state and society to the museum? How responsible is the museum to society and the state?

Z. T.: Different points of view exist on this matter. There is a point of view that a museum is a temple. It is like a holy place, the focus of national artistic memory and national identity quintessence. Well, for example, if we are talking about our museum.
What is clear is that it is the duty of the state and society to finance museums, support, do everything to ensure that museums develop and work better. And so on. Another concept states that a museum cannot survive only within the framework of the system that existed. For us, the idea of relying on sponsors and patrons of art is quite organic since, unlike the Russian Museum and the Hermitage, we were created not by the Emperor, not by the state, but by a private person with his own money. Another concept is that the museum can and should earn money on its own and receive support from businesses - large, small, medium, from any. This concept is actually quite appealing to me. I understand that it began to decline in 2020. Although at the same time, I can say that quite many patrons of the arts understand that the state cannot support all museum initiatives. And these museum initiatives are significant for society. And by supporting this, the patrons really work for society's development, and they are merely interested in it. After all, nowadays, many, both corporations and wealthy people, are also collectors; they are fond of art. It seems to me that this model is optimal: support from the state, in some basic needs, and from business and society. Most importantly, it appears that today, the understanding is very clearly formulated that a museum is primarily for people and not for museum workers and specialists. It is not for me to tell you how often you have come across this concept: here is our research... Excuse me. Pavel Tretyakov conceived it as a museum for the people. Moreover, he even designed it as a museum with free admission. We cannot afford it. Alas.

Today, for us, one of the main vectors of what we have been doing in recent years is that we have been doing this for people, for society, for the people who live in our country, for those who come from all over the world. By the way, 13 percent of our audience is international, and 87 percent is the Russian audience.

Without museums during a pandemic, it would have been difficult for society. Without artistic ones first of all. Well, imagine that all art museums in the world are closed for a long time. And we are left without art. How is it? Especially now. You know, I thought a lot about this, our colleagues thought about it both at the Tretyakov Gallery and in other museums. It is no coincidence that a few years ago, we created a large-scale concept for the development of the Tretyakov Gallery, where we for- 
mulated both the primary mission of the museum and the need to face the public, society, which desperately needs what we are doing.

During the quarantine period, more and more often, there were thoughts that today we, unfortunately, are very busy with the daily hustle and bustle. We sacrifice our relationships, relationships with our family to work. It will have grave consequences. We cut off personal connections, contacts. We deprive ourselves of a lot. We need some compensation.
And the museum is the place where you can come, get the strongest emotions, impressions. I think that intuitively many people understand that a museum, art, theater, concert hall, music provide something without which a person cannot exist. You can give up a lot; however, still, there is a need for an emotional shock with a positive sign. And you get it in a museum. Well, I will repeat what all my colleagues said: when we were in quarantine for many months, it was art that saved us. 


\section{DOI: 10.36340/2071-6818-2021-17-1-10-28}

Журнал традиционно открывает «Академическое интервью». В этом номере мы представляем генерального директора Государственной Третьяковской галереи Зельфиру Исмаиловну Трегулову, которая любезно согласилась ответить на вопросы главного редактора журнала «Дом Бурганова. Пространство культуры» Марии Александровны Бургановой и представила неизвестные странищы истории Третьяковской галереи. 


\section{ИНТЕРВЬЮ С ГЕНЕРАЛЬНЫМ ДИРЕКТОРОМ ГОСУДАРСТВЕННОЙ ТРЕТЬЯКОВСКОЙ ГАЛЕРЕИ ЗЕЛЬФИРОЙ ИСМАИЛОВНОЙ ТРЕГУЛОВОЙ}

Мария Бурганова: Третьяковская галерея сокровищница русского искусства, символ отечественной культуры. Для одних - это место паломничества, для других - часть личной биографии. В этой связи проще избрать консервативность как стратегию существования. Накопленные шедевры - уже залог стабильности, которой так не хватает современному миру. Но сегодня Музей, избрав темп стремительного движения в мире искусства, всё больше ассоциируется с авангардом в культуре и актуальными процессами в искусстве.

Новые стратегии развития не затмевают узнаваемый и любимый образ традиционного московского музея?

Зельфира Трегулова: Понятно, что для огромного количества людей Третьяковская галерея ассоциируется со зданием в Лаврушинском переулке, с классической экспозицией русского искусства, начиная от древнерусского хронологически, и далее - с XVIII века до символизма и «Голубой розы». Сама коллекция древнерусской иконы в Третьяковской галерее потрясающая и великолепная. Её действительно трудно с чем-то сравнить.

Но, давайте задумаемся вот о чём. Павел Михайлович Третьяков - человек, который в 26 лет начинает коллекционировать произведения искусства, - покупает, например, картину «Стычка с финляндскими контрабандистами» художника В. Худякова или картину Н. Шильдера «Искушение» с изображением сводни, которая приходит в дом к бедной семье, где больная мать, прекрасная молодая девушка... Картины, в которых превалирует сюжет и назидательность. Так вот в 26 лет, когда Третьяков в первый раз собрался за границу, перед тем как уехать, он написал завещание, в котором сформулировал своё кредо - создание музея, представляющего национальную школу, музея, от которого «будет польза для многих и удовольствие для каждого». И что начинает делать этот человек, который за свою жизнь побывал в 253-х городах Европы? Если сло- жить поездки всех нас, нескольких человек вместе взятых, очень активных последние тридцать лет, - не наберётся 253 города Европы. Всюду знакомясь с новейшими технологиями производства текстиля, Третьяков одновременно посещал музеи. Так вот, что он начинает собирать? Он начинает собирать современное искусство, начинает приобретать работы молодых передвижников, которым и не было тридцати, работы молодого Репина. В конце концов уже в более поздние годы, если вы помните, Третьяков покупает «Девушку, освящённую солнцем» В. Серова. Это 1888 год. А годом ранее он пытался приобрести «Девочку с персиками». Так вот, когда он купил «Девушку, освящённую солнцем», то тут же столкнулся с реакцией злой и порой вульгарной критики. Так же, как Ренуар, - за его потрясающую «Обнажённую» с голубыми тенями, ту, что сейчас в ГМИИ им. А.С. Пушкина. Очень похоже...

Он покупал работы Верещагина, картины которого вызывали серьёзнейшую критику за отсутствие патриотизма. Травля развилась до такой степени, что, как известно, Верещагин сжёг три или четыре работы, которые вызвали наиболее яростную критику. Третьяков купил всю его «Туркестанскую серию» с такими неоднозначными, даже для сегодняшнего восприятия, работами, как «Апофеоз войны». То же можно сказать о покупке картины «Иван Грозный и сын его Иван», на которую напали первый раз в 1913 году.

Если пройти по залам Третьяковской галереи, то понятно, что действительно, Третьяков собирал актуальное искусство, чувствуя самых важных художников, - интуиция была потрясающая. Заказывал работы, покупая на корню в мастерских лучшие работы, на некоторых порой в тот момент ещё не просохли краски.

Сегодня в сознании многих сформировался образ Павла Михайловича Третьякова как сурового человека в сюртуке, застёгнутом на все пуговицы. На самом деле это был невероятной смелости человек, который тратил, будучи очень успешным бизнесменом, всю свою жизнь на создание 
музея русской национальной школы. Музея, о котором тогда не думало ни государство, ни Государь Император.

Поэтому собирание актуального современного искусства и демонстрация его - это исторически сложившаяся роль Третьяковской галереи. И это объективно так. Необходимо вспомнить, что те художники, работы которых покупал Третьяков, были совсем молодыми людьми. Да, понятно, что тогда и взрослели пораньше, и зрелость обретали пораньше. Вспомним «Бурлаков на Волге» - Репину, когда он начал работать над этой картиной, было 26 лет.

Третьяков также купил работы Николая Ге, которые при его жизни не показывались, поскольку находились под запретом цензуры. Они висели за чёрными занавесочками. И Третьяков не дожил до того момента, когда запрет цензуры на картины Ге был снят.

Позже в собрание Третьяковской галереи вступает коллекция Михаила Абрамовича Морозова, умершего в 1903 году. Коллекция, в которой была блистательная «Жанна Самари» Ренуара, «Девушки на мосту» Эдварда Мунка. В дальнейшем работы, которые после 1917 года были отделены от работ русских художников, были распределены между ГМИИ им. А.С. Пушкина и Эрмитажем.

Я думаю, что ни один музей, который собирает произведения невероятного большого хронологического отрезка, музей национального искусства, не может поставить точку в какой-то момент и прекратить покупать современное ему и актуальное, не в смысле определения значения актуального искусства, а то искусство, которое рождается сегодня. Да, стоит вопрос: а как вы можете знать, что этот художник будет великим? Ну Павел Михайлович тоже собирал и работы, которые сегодня не кажутся работами великих художников, но они в любом случае интересны. Сейчас мы пытаемся показывать тех же передвижников не только знаменитыми хрестоматийными работами, а показывать то, что обычно находится в фондах, и это создаёт очень интересный контекст для этих главных шедевров. Там множество открытий, а мы на самом деле в понимании того, что такое русское искусство, очень долго были крайне консервативны. Советское искусствознание крайне тому способствовало.

И мы сегодня не только показываем современное искусство и принимаем его в дар, потому что возможности покупать у нас крайне ограничены, но и создаём очень современные выставки классического русского искусства, выставки, в каждой из которых есть какая-то современная линза, какой-то современный фокус. Выставки, которые пытаются отбросить предвзятые мнения, штампы, стремятся анализировать художественный феномен максимально объективно и возвращать этому искусству те смыслы, которые присутствовали при его рождении, которые считывались тогдашней критикой, но которые за годы советской власти были напрочь забыты, на которые не обращали внимания, которые были вытравлены из сознания. Примеров неверной интерпретации советским искусствознанием множество. Например, «Неизвестная» Крамского... Наверное, вы хорошо помните время, когда говорили, что вот это Анна Каренина, а потом я испытала настоящее потрясение, когда Михаил Михайлович Алленов, наш университетский преподаватель и мой учитель, объяснил, что это дама полусвета на Аничковом мосту, что мы потеряли социальный код, что не может днём без сопровождающего, без вуали, в открытой коляске ехать женщина высокого социального статуса. Или «Не ждали» - работа на современный сюжет, в котором в советские годы видели только злободневность. На самом деле современники Репина прекрасно понимали, что это парафраз одновременно и «Явления Христа народу» и «Притчи о блудном сыне». Эта христианская иконография и попытки обратиться к вечным темам, у того же Репина, например, замалчивалось в течение огромного количества десятилетий. И мы сегодня возвращаем эти смыслы вновь. И это становится невероятно интересным и актуальным. Этими выставками на самом деле мы пишем новую историю отечественного искусства.

Если вернуться к зданию Третьяковской галереи на Крымском Валу, то многие годы, когда я ещё не работала в галерее, каждый приход в это здание будировал мучительный вопрос, поскольку, если там только не шла выставка Левитана или Нестерова, в огромном гардеробе можно было увидеть всего лишь 20 пальто. Вы прекрасно помните пустые залы на выставках авангарда. Может быть, посетители были на первых двух-трёх выставках - 1990-х Малевича, Филонова, Поповой... Как будто проклятье висело над этим зданием, этим пространством. Поэтому мы за последние годы приложили огромное количество усилий на то, чтобы заставить людей 
гордиться русским авангардом, заставить людей понимать, что отечественное искусство XX века отмечено высочайшими достижениями, причём достижениями мирового масштаба, в не меньшей, а иногда и в большей степени, чем классическое русское искусство.

Сейчас этот перекос немного выравнивается, потому что чем дальше, тем больше русское искусство XX века вызывает огромный интерес, и одновременно формируется очень современный подход к показу отечественного искусства тот подход, который обеспечил нам эти гигантские очереди. Очередь на Серова - почти 500 тысяч человек. 600 тысяч - на Айвазовского. Когда мы начали работать над этой выставкой, я думала, как же мы будем сегодня показывать Айвазовского? А нужно было просто отбросить снобизм, вглядеться в него. Не случайно его называли русским Тернером. Вот именно это противоборство вселенских стихий стало важнейшей темой творчества обоих. И на самом деле, лучшие полотна Айвазовского - это про всевластие стихий и ничтожность человеческого существа по сравнению с масштабом мироздания. Мы начинали эту выставку с видеоарта группы «Синий суп», с никак не расступающегося перед тобой бесконечно движущегося моря. Такое, знаете, совершенно гипнотизирующее зрелище. И сразу оптика при заходе на выставку настраивалась не на прекрасные лунные и закатные, морские пейзажи, так востребованные на художественном рынке, и зритель начинал искать в этом художнике что-то другое. Опять же более глубокие смыслы, а он был человеком, знакомым с самыми серьёзными философскими и религиозными учениями. Благо его брат Габриэл прожил долгие годы в монастыре святого Лазаря в Венеции.

Моё глубочайшее убеждение, что музей сегодня не может быть консервативным. Роль музея сегодня невероятно активна. И музей сегодня может очень многое сделать. И это не мода, как многие говорят. Хотя что плохого в том, что ходить в музей модно? Крымский Вал до наступления пандемии - это было невероятно живое, активное, бурлящее место, где одномоментно происходило множество всего. Были концерты, были философские дискуссии, лекции, показы кино, выставки, причём разного рода. Мы отреставрировали внутренний двор, создали кафе, где люди просто встречались, т.е. сделали это важнейшим общественным пространством. А сегодня люди, которые всё больше и больше изолируются друг от друга и от своих близких, испытывают некую потребность социализироваться. И вот музей становится в том числе и точкой социализации. Это невероятные эмоции, это противовес, противодействие фейкам, потому что искусство всегда говорит правду, свою собственную правду, оно не лжёт, ну, если это настоящее искусство. Априори, то что мы показываем - это настоящее искусство. Это потрясающие эмоции, которых нам не хватает в каждодневной, невероятно суетной, сосредоточенной в первую очередь на работе жизни. Музей - это место, куда ты можешь прийти с семьёй. Ну и многое, многое другое. И не понимать это изменение, эту социальную роль музея - неправильно.

М.Б.: В последнее время Третьяковская галерея осуществила цельй ряд проектов, представляющих диалог культур. Например, чтобы представить творчество М. Ларионова, вы сотрудничали с Центром Помпиду, Музеем Людвига и Галереей Тейт. В 2019 году на своей площадке развернули экспозицию норвежского живописца Э. Мунка, в 2020 - маситабный проект «Библия Пискатора - настольная книга русских иконописцев». Примеров множество.

Как воспринимают наш национальный музей в международном арт-пространстве?

3. Т.: Тоже хороший вопрос, который никто не задавал. Мы сделали за последнее время несколько очень важных, высочайшего класса смело могу сказать это - международных проектов. Я бы хотела выделить в первую очередь три замечательных альянса с серьёзнейшими европейскими музеями, сейчас будет четвёртый. Первый проект - это проект с Национальной портретной галереей в Лондоне. Мы сделали обмен с ними привезли выставку 49-ти портретов из постоянной экспозиции Национальной портретной галереи. В ответ отправили 26 лучших портретов русский художников. Наша выставка вызвала огромный интерес. Лондонские коллеги выделили под неё два относительно небольших зала. Потом страшно сожалели об этом, потому что люди толпились как сельди в бочке. Мы дали лучшие произведения, и они дали свои лучшие произведения.

Второй обмен был с музеями Ватикана. И при этом мы следовали принципу паритетности. Мы каждый раз давали западным кураторам, которые формировали выставку из собрания Третьяковской галереи, карт-бланш, но в ответ также 
просили карт-бланш на формирование выставки из их собрания. Это невероятно срабатывало. Куратором в ватиканский проект я пригласила Аркадия Ипполитова. Мы совпали в отборе основных произведений для выставки, включая «Положение во гроб» Караваджо. Это были 42 произведения живописи со стен Пинакотеки Ватикана. Ни одна работа не была из запасника. «Положение во гроб» Караваджо; «Мученичество Святого Эразма» Пуссена, написанное для собора Святого Петра, 3 метра 20 см высотой; потрясающее, феноменальное «Оплакивание» Джованни Беллини; три из пяти Ангелов Мелоццо да Форли, которые являются символом-знаком Пинакотеки Ватикана; Рафаэль...; Веронезе...; первое в мире изображение Франциска Ассизского начала XIII века; икона XI века, созданная до схизмы, изображающая Спасителя; феноменальное «Оплакивание» Кривелли. Ну вот сейчас говорю - и мурашки по коже.

Произведения, которые мы отправили в Музеи Ватикана, были представлены в крыле Карла Великого собора Святого Петра. Сергей Чобан сделал совершенно потрясающую экспозицию, встроенную в архитектуру Бернини. Пространство поднималось вверх, и проход по выставке был, как некое восхождение. Кураторы выставки Аркадий Ипполитов и Татьяна Юденкова предложили интереснейший ход - выставка называлась «Русский путь: от Дионисия до Малевича». Впервые в истории древнерусская иконопись была показана вместе со светской живописью второй половины XIX - начала XX века, демонстрируя, что русское искусство - это единое целое. Когда «Чёрный квадрат» Малевича висел рядом с огромной Новгородской иконой XVI века «Страшный суд» - то всё было понятно. Когда «Христос в пустыне» Ивана Крамского находился совсем недалеко от портрета Достоевского работы Василия Перова, а в центре зала перед ними стояла пермская деревянная скульптура - стало видно общее: и у Христа из Перми, и у «Христа» Крамского и у Достоевского было то же сосредоточенное выражение лица, те же мучительно сжатые в замок руки и те же самые мучительные вопросы вставали перед внутренним взором.

Мне выпала феноменальная честь 40 минут показывать эту выставку Папе Франциску. И я, честно говоря, нервничала, потому что его английский не очень хороший, а мой итальянский откровенно плох. Но когда он остановился у этих трёх произведений, он оглянулся вокруг и сказал: «Смотрите, это же один и тот же образ», т.е. он увидел в Достоевском «Христа» Крамского. А надо сказать, что портрет Достоевского Перова был создан в том же 1872 году, что и «Христос в пустыне» Крамского.

Третий обмен - наша выставка в музее Мунка в Осло, представлявшая искусство рубежа XIXXX веков, ставшая самой посещаемой выставкой в истории музея Мунка. И феноменальная выставка Мунка из собрания музея Мунка, закрытого на тот момент, у нас. Директор норвежского музея сказал, что это лучшая выставка Мунка из собрания их музея за последние десятилетия.

А сейчас у нас обмен с Хельсинки. Мы совместно с Русским музеем направляем в Музей Атенеум Репина, а в 2022 году принимаем выставку главного финского художника - Аксели Галена-Каллела. Опять же музей в Хельсинки будет закрыт на реконструкцию -и мы привезём все самые уникальные вещи.

И отвечая на вопрос, если бы мы сейчас не повысили градус своей репутации в мире, наверное, мы бы не получили под свою кровлю все эти феноменальные шедевры, включая самую раннюю версию «Крика» Э. Мунка. Ну про «Положение во гроб» Караваджо я молчу. Честно, пока выставка не была отвезена в обратно в Рим и не распакована, я каждый вечер ложилась с мыслью «Господи! Дай Бог, чтобы всё, вот всё, было хорошо». Никогда под крышей Третьяковской галереи не было таких вещей общемирового статуса, если не считать авангард. Но всё равно, когда мы говорим о «Положении во гроб» Караваджо, то необходимо осознать - это один из главных шедевров мировой живописи И нам это доверили. У нас ни с одним из этих музеев никогда не было никаких финансовых условий, чтобы мы платили за предоставление работ. Конечно, нет. И это сотрудничество, паритет. Это может быть такой off records, но только четыре года назад Третьяковская галерея стала членом группы Бизо - сообщества директоров крупнейших музеев мира, участников международного выставочного процесса. И я стала первым директором музея национального русского искусства, который вошёл в эту группу. Конечно, ситуация за последние годы менялась. Понятно, что мы очень востребованный музей, если говорить о коллекции русского авангарда. Число запросов на эту часть коллекции сравнительно 
с нашими другими собраниями огромно. И мы стараемся каждый раз, когда нам предлагают участие в каком-то серьёзном важном проекте, в нём участвовать и авангардом, и искусством девятнадцатого века.

Например, в Париже несколько лет назад в Пти-Пале проходила выставка L'art de la paix («Искусство мира»), посвящённая теме мира, она начиналась договором, подписанным Карлом Великим, из Национальной библиотеки в Париже и завершалась «Апофеозом войны» Верещагина, и эта картина звучала как невероятный призыв ко всем: не вести войны.

Выставки из наших собраний регулярно можно увидеть за рубежом, в частности, в Китае. Несколько лет назад наша выставка передвижников была признана самой лучшей выставкой искусства XIX века в мире в тот год. И это понятно - «Вечерний звон», «Неизвестная» Крамского - китайцы просто плакали на открытии. Это не преувеличение. На вернисаж были приглашены 10 профессоров местной Академии художеств, которые когда-то учились в России или у русских учителей. И эти люди к раме «Неизвестной» прикасались, как будто к иконе.

М.Б.: В программе выставочных проектов Третьяковской галереи 2021 год ознаменовался замечательным проектом «Лаборатория Будущего. Кинетическое искусство в России», который посвящён одному из интереснейших направлений современного искусства - кинетическому искусству. Среди художников Наум Габо, Вячеслав Колейчук, Эль Лисицкий, Натан Певзнер, Александр Родченко, Владимир Татлин и многие другие. Это маситабный проект, объединяющий сотни шедевров. Как пришло осознание его необходимости? Известно, что в настоящее время планируется воссоздание и установка в Москве 13-метровой свето-динамической композиции «Атом» В. Колейчука.

Это свидетельствует о новых тенденциях в культурном пространстве города?

3. т.: По поводу кинетизма. Когда заходишь на выставку - у тебя мурашки по коже. Так это здорово. Причём это очень тонкая и умная история. Это невероятная экспозиция, как бы рассказывающая о нашем первородстве, я имею в виду конструктивизм. На самом деле это тот редкий случай, когда реконструкции произведений конструктивистов, выполненные Вячеславом Колейчуком, не смотрятся новоделом. Это та же самая концепция, заново рождённая через многие десятилетия. И выставка очень ярко рассказывает, как идеи конструктивизма переплетаются с работами конца 50-х - начала 60-х годов художников оттепели. Ты понимаешь их связь с конструктивизмом, и понимаешь, что это совсем другое - другой этап. Эти работы 19591962 годов невероятны по своей оригинальности и смелости. Сталин умер в 1953-м, был железный занавес. То, что мы видим в работах молодых Франциско Инфанте, Льва Нусберга, Игоря Злотникова - это не только интерес к современному искусству Запада, полученная опосредованно через польские художественные журналы информация, это рождение в сознании молодых советских художников схожих идей, идей, актуальных для конца 1950-х - начала 1960-х, идей, которые возникают у советских художников иногда раньше на год, полтора, чем у их западноевропейских коллег. Об этом же говорил Петер Вайбель, директор ZKM в Карлсруэ, когда мы работали над выставкой «Европа лицом к будущему», которая состоялась в Пушкинском музее, я была связана с этим проектом, когда была ещё директором РОСИЗО. И действительно, сопоставляя даты, он сказал, что Советский Союз и Загреб были теми первыми точками, где рождалась кинетика и геометрическая абстракция этого периода. Ну мы не берём в расчёт монументальную геометрическую абстракцию и американский абстрактный экспрессионизм. Мы говорим про Европу. И потом очень интересно видеть, как лучшие идеи конструктивизма, идеи художников оттепели заново становятся актуальными уже в работах современных художников. За этим процессом невероятно интересно следить. Экспозиция выстроена таким образом, что любой проход по этой выставке - это невероятное путешествие с вечно меняющейся точкой зрения. Действительно, я не думала, что это будет так восхитительно. Я просто счастлива, что на этой выставке очень много работ Вячеслава Колейчука, потому что я испытываю чувство вины, что мы не смогли сделать его выставку при его жизни. Сейчас будем делать.

Это родство кинетического искусства с русским авангардом - суть любого всплывания на поверхность художественного процесса аналогичных идей. И в этом особенность русского искусства двадцатого века. И мы хотим это показывать, обладая серьёзнейшим собранием русского авангарда, 
понимая, что это наследие действительно где-то на генетическом уровне, на уровне концепции художественной идентичности в стремлении всегда выйти к абсолюту, достичь абсолютного выражения идей, крайне важно артикулировать.

Когда в 2011 году после выставки Пикассо в Москве я попала в музей Пикассо в Париже, открытый после реконструкции, я стала задавать себе вопросы. Я увидела графические листы Пикассо 1913-1914 годов, с протосуприматическими элементами. И увидела бумажные и картонные как бы контррельефы того же периода. И сразу пришло сопоставление с русским искусством с работами Малевича и Татлина. Они противоположные художники, но оба переживали в этот момент период сильнейшего увлечения Пикассо. Пикассо был первым, кто приблизился к эти двум идеям протосупрематизма и протоконструктивизма, а потом, наверное, его пристрастие к плоти живописи, и вообще темперамент, повернул его творчество в другом направлении. А русские Малевич и Татлин - развили это до абсолюта. Самые радикальные художественные произведения 1910-х годов - это «Чёрный квадрат» Малевича, «Контр-рельеф» Татлина и «Три цвета. Желтый. Красный. Синий» Родченко, «Зелёная полоса» Розановой. И посмотрите, что осталось сделать американской геометрической абстракции послевоенных лет? Ничего. Всё было сказано.

М. Б.: В связи с Covid-2019 пространство культуры стало виртуальным. Здесь есть преимущества - можно за один день посетить музеи Москвы и Парижа; но есть и недостатки - среди них не только невозможность встречи с подлинником, но и невозможность войти в музейные залы.

Стоит ли сожалеть о наступлении новой виртуальной эпохи в культуре? Можно ли сохранить в этом контексте уникальность музея, ведь медийные инструменты универсальны и обезличены?

3. Т.: Я говорила, и глубоко убеждена в том, что одно другому не мешает. Мы же с вами постоянно ходили в музеи. Постоянно соприкасались с художественными произведениями, часто ходили в театр и на концерты. И потом, весной, в начале лета 2020 три с половиной месяца абсолютного карантина, когда альтернативы нет, когда мы работаем в Zoom с десяти до семи, ощущая себя в конце дня как будто по тебе каток проехал, потому что, чтобы через это нейтральное виртуальное пространство передать энергетику, необходимую для правильной коммуникации, истрачиваешь её во много раз больше, чем когда ты общаешься вживую.

Так вот, эти три с половиной месяца мы все одинаково проживали вечера в пространстве искусства онлайн. И оно нас спасало. Но при этом все прекрасно понимали, что очень хочется опять оказаться в реальном музейном пространстве перед реальными произведениями Ранней весной 2020 мы прекрасно понимали, что нас будут закрывать. И мы бросились создавать онлайн-контент, в том числе фильмы, например, «Третьяковка с Сергеем Шнуровым». И, полагаю, мы создали новый формат онлайн-разговора об искусстве в музее. Это не был подготовленный текст, это не было отрепетировано, это была настоящая импровизация. Создавалось ощущение непосредственности. Ощущение, что ты стоишь за спинами этих двух людей, таких разных, говорящих о той или иной картине. И со Шнуровым, надо сказать, было очень интересно.

Так вот, как хотелось тогда вернуться в музей, как хотелось вернуться в концертный зал. Когда я услышала про концерт Мацуева в Концертном зале Чайковского, первый, после карантина, немедленно побежала слушать и поняла, что при том, что я жила во время карантина в мобильных наушниках, бесконечно слушая классическую музыку, потому что нужно было заполнять этот вакуум чем-то, что бы тебя держало на плаву, было необходимо вернуться в реальный концертный зал или в пространство музея. Когда слушаешь живую музыку, понимаешь, что ты готов ходить на эти концерты, в реальные музеи бесконечно.

Да, конечно, благодаря ситуации с онлайнактивностям мы смогли сделать гигантский прорыв. За это время аудитория увеличилась в разы. У нас 10 миллионов просмотров нашего онлайнконтента за прошлый год. На YouTube мы первые в мире по числу подписчиков. И программу «Третьяковка со Шнуровым» посмотрели только у нас на YouTube миллион сто тысяч человек. И эти миллион сто тысяч человек поняли, что музей - это не скучное место, куда тебя привела «училка по обязаловке» и куда ты больше не вернёшься и уж точно не приведёшь своих детей. При этом никоим образом мы не пытались работать так, чтобы это было чистой воды популизмом. Мне многие говорили, что ждали до конца, когда наконец Шнур начнёт использовать 
ненормативную лексику. Но, не случилось и не могло случиться - он крайне умный и образованный человек.

Вот поэтому для меня это взаимодополняющие реальности. Когда во времена коронавируса закрываются двери музея, концертных залов, театров, онлайн - единственная альтернатива. Настраиваешься на энергетику записи, видео, аудио, но когда потом имеешь возможность вернуться к оригиналу - подсознательно сравниваешь и понимаешь ту огромную разницу, которая существует между реальным и виртуальным. Поэтому я абсолютно не боюсь, что виртуальная реальность в данном случае вытеснит живой реальный музей. Наоборот, это подготовит аудиторию, публику, как бы зацепит её. Но нужно для этого делать очень современный контент. Современный не в смысле технологии. Например, мы снимали фильм о Третьяковке со Шнуром, потом о Третьяковке с Хабенским, с помощью трёх-четырёх камер. Никаких комбинированных съёмок, никакой виртуальной реальности. Это была живая реальная съёмка. И она была не скучной. Она была живая, ты видел эмоцию на лицах говорящих. Ты впитывал их энергетику. Через тебя шла передача вот этого божественного смысла, содержащегося в каждом художественном произведении, тем людям, которые сидели перед экранами телевизора, компьютера, айпада, айфона - чего угодно.

М. Б.: Общество создаёт музей - музей создаёт общество. Какую ответственность несут государство и общество перед музеем? Насколько музей ответственен перед обществом и государством?

3. Т.: Здесь есть разные точки зрения. Есть точка зрения, что музей - храм. Как бы святое место, средоточие национальной художественной памяти, квинтэссенция национальной идентичности. Ну, например, если речь идёт о нас. И, что понятно - это обязанность государства и общества финансировать музеи, поддерживать, делать всё для того, чтобы музеи развивались, работали лучше. И так далее. Есть другая концепция, что музей не может оставаться только в рамках той системы, которая существовала. Для нас идея опоры в том числе и на спонсоров и меценатов вполне органична, потому что в отличие от Русского музея и Эрмитажа нас создавал не Государь Император, не государство, а частное лицо, на свои заработанные деньги. Другая концепция - что музей может и должен зарабатывать деньги сам, и получать поддержку со стороны бизнеса крупного, малого, среднего, мелкого - любого. Мне эта концепция на самом деле достаточно импонирует. Я понимаю, что в 2020 году она начала сворачиваться. Хотя при этом могу сказать, что довольно многие меценаты понимают, что у государства нет возможности поддерживать все музейные инициативы. А эти музейные инициативы крайне важны для общества. И поддерживая это, меценаты действительно работают на развитие общества и им просто это интересно. Ведь очень многие сейчас - и корпорации, и состоятельные люди - ещё и коллекционеры, они увлекаются искусством. И мне кажется, что оптимальна вот эта модель - поддержка и государства, в каких-то основных нуждах, и бизнеса, и общества. И главное, мне кажется, что сегодня очень чётко формулируется понимание, что музей - в первую очередь для людей, а не для музейщиков и специалистов по преимуществу. Не мне вам говорить, как часто вы сами сталкивались с этой концепцией: вот наши исследования, вот наши изыскания... Простите. Павел Михайлович Третьяков его задумывал как музей для народа. Более того, он даже задумывал его как музей с бесплатным посещением. Мы себе этого позволить не можем. Увы.

Сегодня для нас один из главных векторов того, что мы делали последние годы, - что мы делали это всё для людей, для общества, для народа, который живёт в нашей стране, для тех, кто приезжает со всего мира. У нас международная аудитория, кстати говоря, - 13 процентов, 87 процентов - это российский зритель.

Без музеев во время пандемии обществу было бы тяжело. Без художественных - в первую очередь. Ну вот, представьте себе, что в мире надолго закрываются все художественные музеи. И мы остаёмся без искусства. Ну как? В особенности сейчас. Вы знаете, я много над этим думала, об этом размышляли наши коллеги и в Третьяковке, и в других музеях. Не случайно, что несколько лет назад мы создали масштабную концепцию развития Третьяковской галереи, где сформулировали и главную миссию музея, и необходимость повернуться лицом к публике, обществу, которым крайне необходимо то, что мы делаем.

В период карантина всё чаще возникали мысли о том, что сегодня мы, к сожалению, очень заняты каждодневной суетой. Мы приносим свои 
личные отношения, отношения со своей семьёй в жертву молоху работы, это будет иметь очень серьёзные последствия. Мы обрываем личные связи, контакты. Сами себя очень многого лишаем. Нам нужна какая-то компенсация. И музей - это то место, куда можно прийти, получить сильнейшую эмоцию, впечатление. Я думаю, что интуитивно очень многие понимают, что музей, искусство, театр, концертный зал, музыка дают то, без чего человек не может существовать. Можно отказаться от многого, но всё равно есть необходимость в эмоциональном потрясении с положительным знаком. И в музее ты его получаешь. Ну и повторю то, что говорили все мои коллеги: когда мы многие месяцы были на карантине, мы спасались именно искусством. 